\title{
Artes de Acontecer: viados e travestis na Cidade do Rio de Janeiro, do Século XIX a 1980**
}

\author{
Arts of Happening: faggots and queens in Rio de Janeiro City, \\ from 19th century to $1980 \mathrm{~s}$
}

Rita de Cássia Colaço Rodrigues**

Resumo: A cidade exibe o resultado dos esforços, mais ou menos rígidos, pouco ou mais frequentes, em conformidade com as conjunturas, tendentes à supressão ou ocultamento de personagens não assimiláveis ao padrão de existência e sociabilidade hegemonizado e incorporado pelos detentores do poder de regulação em cada regime. À parte esses processos, cujas marcas são caracteristicamente as fantasias higienistas e o apego a uma moralidade, via de regra, bifronte, os atores que resistem subalternizados em seus desvãos mostram-se ricos em práticas inventivas, desenvolvendo mecanismos próprios, capazes tanto da conquista de territórios como de constituir redes de articulações impensáveis. Conjugando o método indiciário com a perspectiva da história vista de baixo, este artigo apresenta uma primeira leitura da investigação sobre a presença de sodomitas, bagaxas ou não, travestis, transformistas e homossexuais masculinos na cidade do Rio de Janeiro, do século XIX à década de 1980, a partir dos espaços de sociabilidade e sexo que foram capazes de conquistar. Tais territórios, ademais de provedores de diversão e satisfação sexual, possibilitaram a superação do desenraizamento e da atomização, a formação de redes de apoio e de carreiras profissionais. Coletivizados, tornaram-se capazes de melhor responder à desigual correlação de forças presente na sociedade ampliada, refratária à sua forma de desejo, estilo pessoal e de gênero.

Palavras-chave: Homossexualidades masculinas; territórios; rio de janeiro

\footnotetext{
* Este artigo é uma primeira leitura das pesquisas em curso sobre a homossexualidade mas-
} 
culina na Lapa e no Centro da cidade do Rio de Janeiro e o projeto de constituição de fontes audiovisuais sobre memórias das trajetórias das travestis transformistas.

**Rita de Cássia Colaço Rodrigues é Doutora em História Social pela Universidade Federal Fluminense (2012), Mestre em Política Social pela mesma Universidade (2006) e Bacharel em Ciências Jurídicas e Sociais pela Universidade Federal do Rio de Janeiro (1988). Áreas de interesse: relações de poder, representação social, dominação simbólica, processos de estigmatização, história da sexualidade, relações de gênero, campo judicial, direito, direitos humanos, camadas populares, memória, homossexualidades, homofobia, história do movimento homossexual brasileiro, proteção social, sociabilidades, territórios, expressões culturais. E-mail: ritacolacobr@yahoo.com.br

\begin{abstract}
The city exhibits the results of more or less hard, sometimes frequent or not, in accordance with the conjunctures, efforts that tend to suppress or conceal characters that are not considered acceptable under the existence and sociability standards, hegemonized and incorporated by the holders of the regulation powers in each regime. Despite these processes, whose marks are, fragrantly, the hygienist fantasies and the attachment to a morality that has, as a rule, two faces, the actors that subordinately resist in its neglected spaces demonstrate rich inventive practices, developing their own mechanisms, being capable of conquering territories as much as construct unimaginable articulations webs. Combining the evidential paradigm with the history from below perspective, this article presents a first perusal from the investigation about the presence of sodomites - rent-boys or not -, queens, transformists and male homosexuals in Rio de Janeiro City, from 19th century to 1980s, based on the spaces of sociability and sex that they were able to win. Such territories, in addition to provide fun and sexual satisfaction, they enabled the overcoming of social uprooting and atomization, the formation of support webs and professional careers. Assembled, they became able to better answer to the unequal correlation of forces current in the wider society, hostile to their way of desire, personal style and gender..
\end{abstract}

Keywords: Male homosexualities; territories; rio de janeiro

Como bem observa Michel de Certeau', a cidade engendrada pelo discurso urbanístico opera o recalque de tudo o quanto possa ser lido como poluição (física, mental, sexual, política etc.), como capaz de comprometer o retrato que dela se quer como oficial. Instituída, dessa forma, como um sujeito universal, produto de operações de controle, segregação e invisibilização, a urbe exibe como imagem o resultado caleidoscópico do grau de controle passível de exercício pelos seus poderes regulatórios, formais e informais. Um de seus traços característicos são os esforços, mais ou menos rígidos, pouco ou mais frequentes, em conformidade com as conjunturas históricas, tendentes à 
supressão ou ao ocultamento de tudo o que não seja assimilável ao padrão de existência e sociabilidade mitificado e incorporado pelos operadores desses poderes de regulação. À parte esse processo, que historicamente tem como marca a pretensão a uma dada moralidade e à higienização, a vida que pulsa em seus desvãos opera com códigos próprios, rica em práticas inventivas, capazes tanto da constituição de territórios como de articulações impensáveis. ${ }^{2}$ É o que se constata nas formas de vidas desenvolvidas por todos os segmentos alvos de processos de desqualificação e invisibilização sociais - travestis e homossexuais entre eles - embora a dificuldade de recuperação de suas formas de vida, precisamente pelo processo de estigmatização por eles vivenciado. ${ }^{3}$

Para esses indivíduos, talvez o autor que mais tenha contribuído para o desvelamento dos seus modos de sociabilidades e apropriações dos espaços urbanos tenha sido George Chauncey, debruçando-se sobre a cidade de Nova York. ${ }^{4}$ Ele recuperou a sociabilidade comunitária e os mecanismos de proteção social elaborados pelos gays entre fins do século XIX e início da II Grande Guerra. Marcados constitutivamente pela desqualificação, forçados a viver seu erotismo de forma clandestina, eles se apropriaram de determinados espaços públicos, como esquinas, calçadas, parques e banheiros públicos, engendrando ali subculturas diversificadas. ${ }^{5}$ Nessa pesquisa, Chauncey mostra como tais territórios, tradicionalmente representados exclusivamente sob a ótica moralista como antros de promiscuidade, decadência moral e violência, possibilitaram a constituição de redes de sociabilidade e apoio, provedoras dos sentimentos de integração e pertença - referenciais positivos às suas identidades historicamente deterioradas pelas civilizações monoteístas. ${ }^{6}$ Desses espaços a céu aberto, as diversas redes constituídas ampliaram-se ao longo do tempo. Conquistaram outros espaços (apartamentos particulares, bares, boates com seus quartos escuros, saunas, restaurantes, cafeterias) e criaram instituições próprias, como times esportivos, bailes, concursos de beleza gay, corais, livrarias, jornais, revistas etc. Em 1920, chegaram a contar com três bairros distintos encravados na Greenwich Village, no Harlem e na Times Square, cuja população era dotada de diferentes características étnicas, de classe, estilo cultural e reputação pública.

Esses territórios, mais do que provedores de satisfação sexual, possibilitaram o partilhamento das experiências de exílio e a consolidação de uma identidade comum. Coletivizados, engendraram práticas de cuidado recíproco, constituindo efetivos mecanismos de proteção interpares, elaborando respostas satisfatórias às exigências do viver urbano: desde o aluguel de um apartamento até o emprego capaz de viabilizar não apenas a manutenção material, mas também a ascensão simbólica e econômica, passando por todas as demais questões da sobrevivência material e social nas quais a rede de relações sociais é fator decisivo ao seu equacionamento. Afinal, como observa Carmem Dora Guimarães, é no encontro com semelhantes que se opera a primeira 
ruptura com a condição de extrema vulnerabilidade do indivíduo atomizado, alvo de processos de desqualificação. ${ }^{7}$ Integrados, tornam-se capazes de melhor responder à desigual correlação de forças presente nos ambientes refratários à sua forma de desejo, estilo pessoal e de gênero.

Os sodomitas, pederastas e travestis brasileiros também foram capazes de formas semelhantes de apropriação de espaços públicos, de constituição de mecanismos de sociabilidade e solidariedade. Embora as pesquisas sobre o tema entre nós ainda sejam incipientes, comparadas com as produzidas em países como os Estados Unidos, o que já foi dado a conhecer aponta para a existência das variáveis características das subculturas em diversos pontos do país e em períodos históricos variados. Cidades como Rio de Janeiro, Niterói (Praça do Rinque, anos de 1980), Campos, Salvador, Belo Horizonte (Parque Municipal, em Belo Horizonte, a partir de fins da década de 1920), Juiz de Fora, Porto Alegre (Parque da Redenção), São Paulo, dotadas de centros urbanos capazes de prover condições de existência anônimas e flexíveis, viabilizaram a formação tanto de redes de relações quanto de territorialidades. ${ }^{8}$

Até fins do século XIX, a presença de pederastas nos espaços públicos da cidade do Rio de Janeiro era tão exuberante que foi considerada "acintosa" por médicos que estudaram a prostituição masculina. ${ }^{9}$ Desde pelo menos os anos de 1950, há registros de núcleos de sociabilidades formados na: Cinelândia, Rua do Passeio, Avenida Nossa Senhora de Copacabana, no Edifício Avenida Central, em determinados trechos das praias (de Copacabana - Bolsa de Valores, do Flamengo e de Ipanema). Para os anos das décadas de 1970 e 1980, encontramos referências a territórios conquistados no Parque Lota Macedo Soares (Aterro do Flamengo), na Rua de Santa Luzia, entre a Praça Antenor Fagundes e o Largo da Misericórdia, na Rua México, no quarteirão do atual Ministério da Saúde, na Avenida Augusto Severo, na Lapa, na Rua Alcindo Guanabara (mais precisamente o bar conhecido como "Calça Arriada", logo após o prédio da Câmara de Vereadores), no Cine Íris, na Rua da Carioca, nos banheiros da estação ferroviária Central do Brasil, na praça da Cinelândia e na Rua do Passeio, na esquina com a Rua Senador Dantas..$^{10}$ Surgiram também diversos espaços de diversão, onde os espetáculos montados exibiam elencos formados exclusivamente de uma nova modalidade de travestis, as transformistas, o que possibilitou a construção de diversas carreiras profissionais, várias ainda em atuação. ${ }^{11}$

Durante as décadas de 1950 e 1960, ademais dos parques, de trechos de praias, praças e banheiros (públicos e de cinemas), as opções de socialização constituídas pelos homossexuais masculinos eram as festas residenciais e, posteriormente, em clubes (geralmente desfiles com trajes femininos, parodiando os concursos de misses), a frequência aos programas musicais de auditório e à platéia dos concursos oficiais de misses. ${ }^{12}$ Em praças como Cinelândia, no Centro, e Paris, na Glória, ademais do footing, costumavam 
simular paródias de desfiles de misses a céu aberto, com o que atraíam a atenção e o bom humor dos passantes, além de se divertirem eles mesmos. As entradas do Teatro Municipal, do Hotel Glória e do Teatro Recreio, quando dos concursos de fantasias carnavalescas, também eram espaços preferenciais de reunião e divertimento, onde se aglomeravam por horas, à espera da chegada de seus ídolos, para prestigiar-lhes. As paródias aos concursos de misses eram realizadas na residência de algum dos integrantes do grupo (ou rede) ou em clubes por eles alugados com esse propósito - por exemplo, para a zona sul, o Clube Sírio-Libanês e o Clube Internacional - e propiciaram intensa interação com as redes de outros bairros e cidades (por exemplo: Centro, Praça Mauá, Praça Onze, Colégio, Irajá, São Cristóvão, Campos, Juiz de Fora, Belo Horizonte, Salvador...). ${ }^{13}$ Outras opções preferenciais de socialização eram os programas de auditório da Rádio Nacional, onde compunham os grupos de fãs das cantoras Marlene e Emilinha, que rivalizavam entre si. Muitas das redes de relações que se organizaram nesses espaços tornaram-se coesas ao ponto de atravessarem décadas, chegando até os dias atuais, como provam os integrantes da Associação Marlenistas, passíveis de serem vistos nos eventos evocativos por ela organizados. Os concursos de misses realizados no Maracanãzinho eram outro ponto preferencial de socialização. Estrategicamente, as bichas optavam por ficar nas últimas arquibancadas, de onde, nos intervalos, obtinham grande visibilidade para as paródias ali improvisadas, arrancando aplausos e risadas tanto dos membros de suas redes, como do público em geral. ${ }^{14}$

Para períodos mais remotos também tem sido possível a localização de fontes que documentam a sua presença. Segundo o historiador fluminense Ronaldo Vainfas, à semelhança do que se verificava por toda a Europa, mesmo sendo intensa a execração do "nefando" e "inominável" e a sua criminalização fosse prevista tanto nas normas seculares quanto nas eclesiásticas, "nem por isso deixaram nossos povoadores de praticá-la [a sodomia] à farta. Homens de todas as classes e raças, padres, autoridades, mulheres, crianças, as fontes inquisitoriais revelam-nos ampla variedade de indivíduos e ligames 'nefandos', como então se dizia, espalhados de norte a sul do Brasil." "15 Os registros, embora lacunares em muitos aspectos, prosseguem através dos séculos, até os nossos tempos.

Em 1840, o médico Pires de Almeida relata que na cidade do Rio de Janeiro havia uma "“aluvião de uranistas"” presente "principalmente no "baixo comércio', ocupado majoritariamente por caixeiros de origem portuguesa, "campôneos", mas também "espalhada pela cidade". Segundo este médico, tal população apresentava um "crescimento assustador" (remunerada ou não), ao ponto de se buscar a sua redução por meio da importação de prostitutas européias - as "ilhoas", geralmente oriundas da Madeira e Açores. ${ }^{16}$ Essa estratégia de tentar minimizar as práticas sodomíticas por meio do incremento da prostituição feminina já havia sido tentada, por exemplo, no século XV, tanto 
na França (como "a arma principal dos reis franceses") quanto na Itália - seja com a criação, em 1403, na cidade de Florença, da associação Onestà, seja com a formação da famosa civilità puttanesca, presente em diversas cidades italianas, e que Achillo Olivieri indaga se acaso ela não decorreria, conforme buscado pela Igreja Católica a partir do século XII, da importância atribuída ao papel desempenhado pela cortesã como estratégia de combate à sodomia. ${ }^{17} \mathrm{Nem}$ lá nem cá se obteve o resultado desejado. Tanto que Ferraz de Macedo (1872), outro médico pesquisado por Soares, esperava conter a expansão continuada da pederastia clamando pela intervenção policial - "fosse de que maneira fosse". ${ }^{18}$ Segundo Macedo, havia "grande concentração" de sodomitas e bagaxas nas Freguesias de Sacramento, de Sant'Anna, de Santa Rita, de Santo Antônio, de São José. ${ }^{19}$

A historiadora Mary Karasch informa que as Freguesias de Sant'Anna, Sacramento e São José, segundo o censo de 1849, concentravam a população de libertos no Rio de Janeiro. ${ }^{20}$ Outra sua característica era abrigar diversas casas de zungús. ${ }^{21}$ Frequentadas por escravos, sobretudo os de ganho, libertos e mesmo os fugidos, todos para ali se dirigiam em busca da socialização com os seus iguais. Naqueles territórios próprios, podiam ter acesso às notícias mais atualizadas do seu interesse, beber, comer, dançar, ouvir e cantar as suas músicas e pernoitar e obter sexo. ${ }^{22}$ Se levarmos em consideração que a pederastia era prática usual também entre negros e mestiços, é de se inferir fossem também os zungús espaços de sociabilidade e sexo para sodomitas, bagaxas ou não..$^{23}$

Além das monografias dos dois médicos, a pesquisa realizada pelo historiador Luiz Carlos Soares teve como base os registros policiais do século XIX e o romance Bom-Crioulo, publicado originalmente em 1895, que trata do envolvimento sexual e amoroso entre o marinheiro Amaro e o grumete Aleixo. De autoria de Adolfo Caminha - um ex-tenente da Marinha, que nela esteve de 1883 a 1889 -, traz na contracapa de sua sétima edição a nota de que é "baseado em fato real". ${ }^{24}$ Nele é interessante observar, ademais da menção de ser a homossexualidade uma prática comum entre os da armada, tanto de brancos quanto de negros, marujos ou oficiais, a descrição da naturalidade e da boa vontade que a portuguesa Carolina, dona do "sobradinho" da Rua da Misericórdia convertido em casa de cômodos, imprime ao aquiescer ao pedido de Amaro de que lhes arranjasse um quarto com "uma caminha larga". À concordância, segue-se uma piscadela da portuguesa, cheia de cumplicidade, ao indicar-lhe o quarto do sótão, no qual ficariam melhor instalados. ${ }^{25}$ Tamanha naturalidade de parte da proprietária reforça a informação do médico Pires de Almeida, em 1890, segundo o qual os uranistas podiam recorrer, para os seus encontros sexuais, às hospedarias, aos quartos alugados por hora ou mesmo a habitações próprias, de forma não dissimulada, de notório conhecimento da polícia, que não os reprimia. ${ }^{26}$ Prática, aliás, bastante comum em Portugal, segundo registra Ronaldo Vainfas, relatando a existência de traços de subcultura 
homófila tanto em Paris quanto em Portugal e em algumas cidades da Espanha e da Itália. ${ }^{27}$ Vainfas esclarece, ainda, que "em Lisboa, especialmente, os fanchonos se encontravam em hospedarias, estalagens e tavernas habituais, cortejavam-se na Ribeira, às margens do Tejo". ${ }^{28} \mathrm{E}$, entre nós, ainda hoje é bastante comum em diversas hospedarias para homens e em alguns hotéis populares do Centro da cidade.

A presença dos uranistas na cidade era tão frequente que Pires de Almeida elaborou uma lista dos mais notórios, onde há menção a um Brigadeiro que organizara um "lupanar de belos rapagões em um sobradinho do Largo de São Domingos". ${ }^{29}$ Brasil Gerson é outro que igualmente nos registra a existência de um conhecidíssimo conventilho de invertidos existente na Rua de São Jorge (também chamada de Travessa do Senhor dos Passos, passando oficialmente a chamar-se Gonçalves Ledo em 1921). ${ }^{30}$ Este lupanar situava-se próximo de onde houvera a capela de São Jorge da Irmandade dos Ferreiros e Caldeireiros, demolida em 1855 e em cujo local surgira "um prostíbulo dos mais reles rodeado de sórdidos conventilhos", organizados no interior de "pardieiros que o prefeito florianista Barata Ribeiro destruiu pouco antes da Revolta da Armada em 1893". Pois precisamente em um desses "se haviam aglomerado dezenas de invertidos, pretos e brancos, todos das mais baixas condições e essa sua tão falada moradia coletiva eles a denominavam 'A Doutrina'". ${ }^{31}$

A partir dos relatos desses médicos, Soares sustenta que as práticas homossexuais entre nós, no século XIX, davam-se igualmente em ambientes sofisticados e intelectualizados, envolvendo profissionais de atividades tão diversas como: corpo diplomático, magistério, alto funcionalismo público, artistas de diversas especialidades, altas patentes militares, juristas, parlamentares. Os locais que eles mais frequentavam, fossem ou não bagaxas, eram os teatros quando em função (permanecendo nas suas portas e porões), os cafés, bilhares, botequins e os restaurantes, as casas de banho, as portarias dos conventos e as escadarias das igrejas, procissões e romarias de igrejas diversas, as praças e parques públicos - o Largo do Carmo (depois do Paço e, posteriormente, Praça XV de Novembro, por decreto de 18/02/1890) e especialmente: o Campo de Santana, o Passeio Público e o Rocio (Praça Tiradentes), cujas vegetações exuberantes propiciavam a providencial discrição. ${ }^{32}$ Nas praças era comum vê-los em duplas ou trios, sentados nos bancos, a fumar, conversar e falando e gesticulando "indecências". Nos três territórios acima referidos, sua assídua visibilidade era relatada como "o mais pavoroso cenário da imoralidade", e envolvia "marinheiros, soldados e vagabundos de toda a espécie". ${ }^{33}$ Lamentavelmente, a pesquisa de Soares não pode desvelar os modos de organização e funcionamento da prestação de serviços sexuais realizada pelos bagaxas.

Outros espaços de interação, como já mencionado, eram os mictórios ou sanitários públicos. Pelo menos um deles, popularíssimo, teve a sua 
existência registrada. Trata-se do que existiu próximo ao Largo da Lapa, descrito por Gasparino Damata como "revestido de mármore rosa, [e] chamado na intimidade de 'A Capelinha'. Era passagem obrigatória do 'gay-power' da cidade, a todas as horas do dia e da noite. Sem distinção de classe". Foi demolido em 1963, em um dos vários bota-abaixo da Lapa. ${ }^{34}$

No que toca aos espaços fechados, onde podiam dispor de privacidade, ademais desses espaços de sexo, pernoite e residência referidos, foi encontrado o registro de pelo menos uma casa noturna na década de 1930. É o que se infere da narrativa constante de poema da lavra do pintor Di Cavalcanti, A mocidade com Jaime Ovalle, apresentado com um introito e encimado pelo título de A Lapa dos meus vinte anos, publicado na Antologia da Lapa, organizada por Gasparino Damata: ${ }^{35}$ "[...] Na rua do Lavradio / O bar cabaré Passatempo Internacional / Lá se iam os homossexuais assustados / Galgando as escadas intermináveis / dos grandes sobrados verdes [...]". Pelo que se observa no exame de jornais da época, o sobrado ficava no número 156 da Rua do Lavradio, de esquina com o número 32 da Rua do Rezende. Embaixo havia um bar, frequentado por populares e não raras vezes palco de brigas, as quais terminavam com a intervenção da polícia e da assistência médica pública, segundo pesquisa realizada nos periódicos locais, através da hemeroteca da Biblioteca Nacional. Não foram encontradas, porém, referências nesses jornais sobre a presença, no local, de pederastas ou invertidos no amor. Esse bar e cabaré descrito por Di Cavalcanti leva a indagar se acaso não seria o mesmo sobrado descrito por João do Rio em 1908, quando então se chamava Chat Noir. De propriedade de uma certa Ivone, definida por Paulo Barreto como "mulher barítono" (eufemismo para masculinizada?), onde era servido o "chope nacional" e cujo ambiente conformava, ainda nas palavras do cronista carioca, um "cabaré satânico [...] um cabaré com todo o sabor do vício parisiense, tudo quanto há de mais rive gauche, mais butte sacré", permite a especulação de que talvez se tratasse de ambiente, se não destinado exclusivamente ao público homossexual, ao menos a eles receptivos. ${ }^{36}$

\section{O Casanova}

Outro ambiente, espaço de resistência, por excelência, pela longevidade de sua apropriação como território de entendidos e pela sua significação simbólica e cultural, atravessando momentos críticos, foi o Cabaré Casanova, também na Lapa ${ }^{37}$ Inaugurado em 1937, na Avenida Mem de Sá, nº 25, com o nome de Viena-Budapeste, exibia orquestra de violinos, tornando-se logo um imenso sucesso. ${ }^{38}$ Sua inauguração for um grande acontecimento, segundo um dos memorialistas do bairro, Luís Martins, frequentador da Lapa dos anos vinte 
até este ano de 1937. ${ }^{39}$ Possuía frequência "heteróclita": malandros sentados lado a lado de diplomatas estrangeiros, compositores, atores, pianistas, enfim, a nata da intelectualidade e do mundo artístico. ${ }^{40} \mathrm{E}$ o clima de genuína alegria que predominava em seu interior algumas vezes era cortado por um alvoroço indicativo de briga. A constância nas brigas e as proporções que elas foram tomando, porém, terminaram por afastar o melhor de sua clientela. Não tardou a se consumar o que já se temia. Tão rápido como alcançou o sucesso, entrou em decadência: "No fim do ano [1938] o Bar Viena-Budapeste já era uma ruína, cerrou as portas logo depois." ${ }_{41}$

Na década de 1940 ocorre, de um lado, a renovação da perseguição à prostituição, pela polícia do Estado Novo, dessa vez levando-a para a área do Mangue; de outro, o deslocamento da zona da boemia para o bairro de Copacabana. Tais mudanças representam severos golpes para a vibrante vida noturna da Lapa, que entra em franca decadência. Em razão da Segunda Guerra Mundial, seguindo tantos outros estabelecimentos com nomes germânicos ou que de alguma maneira traziam à lembrança países do então chamado "Eixo", o Viena-Budapeste "Passou a chamar-se 'Casanova'. Logo mudou também de gênero, transformando-se em cabaré, com show de "artistas internacionais".".42

A chegada da década de 1960 traz para a Lapa outro golpe: com a mudança da Capital Federal para Brasília, a cidade já não contava mais com as presenças dos senhores de terras do interior, dos senadores ou deputados federais a movimentar as suas noites. A Lapa tornara-se apenas sombra do que fora nos anos vinte e trinta. No curso dessas transformações, verifica-se o deslocamento da Praça Tiradentes para o bairro da Lapa como local privilegiado de sociabilidade homossexual. ${ }^{43}$ Sintomaticamente, é quando se verifica o arrasamento do tradicional mictório A Capelinha, registrado por Gasparino Damata, compondo um dos bota-abaixo do bairro.

Aguinaldo Silva, novelista e ex-editor do jornal Lampião da Esquina, um dos marcos do movimento homossexual brasileiro, morou na Lapa durante alguns anos da década de 1960 e narrou suas memórias do bairro. Na sua opinião, esse bota-abaixo representava um projeto higienista, para retirar as travestis, tendo em vista as obras para a construção, ali próximo, nas terras resultantes do arrasamento do antigo Morro de Santo Antônio, da nova Catedral Metropolitana. Não é absurda sua hipótese, se pensarmos na tradicional forma de a Igreja Católica tratar os homossexuais no Brasil. ${ }^{44}$ Aguinaldo confirma o registro de Nestor de Holanda, ao elencar as travestis entre os frequentadores da Lapa naquele período: malandros, travestis, alcaguetes, policiais e boêmios, mas, entretanto, não especifica de quais tipos era formada essa boemia. Curiosamente, nenhuma referência faz ao Casanova ou a qualquer território de socialização de viados ou travestis, embora o antigo Viena-Budapeste já apresentasse shows com eles. É através de João Antônio [Ferreira Filho], também escritor, que vamos encontrar um relato sobre os espetáculos de 
travestis, nessa época, na Lapa. Tendo publicado as suas memórias sobre o bairro em 1963, Antônio traz informações importantes sobre os espetáculos dos transformistas, como eram chamadas as travestis que se dedicavam aos espetáculos de canto e teatro musical ou de revista. ${ }^{45}$

Antônio se refere ao antigo cabaré como "Boite". Pois essa boate, situada numa Lapa completamente decadente e agonizante, segundo suas palavras, exibe já por seis meses, “a mesma 'grandiosa produção'... Um show exclusivamente de travestis, bastante movimentado, onze elementos e muita variedade, graças ao talento criador de Nelito Flores". Na visão preconceituosa de João Antônio, a noite da Lapa, no início da década de 1960, permanecia sendo "um reino dourado e saltitante dos invertidos do amor com suas franjinhas delicadas, seus fricotinhos, desmunhecamentos e ares de etéreos sofrimentos". ${ }^{46}$

As transformistas Suzy Parker e Cláudia Celeste, as quais entrevistei, confirmam a forte presença dos shows de transformistas no meio cultural da cidade naqueles anos da década de 1960. Suzy atuou em espetáculos encenados no palco do Casanova. Segundo lembra, fora em 1965, sob a direção de Nelito Flores. Faziam parte do elenco as transformistas: Eloína; Rita Moreno; Fabettte Schüller; Darla Mendes; a estrela principal, Sarita Lamarque; Marisa Chaves (Mário Chaves, entrevistado pelo jornal Lampião da Esquina já avançado em idade) e Aymont (segundo Ivaná, o precursor do transformismo no Brasil e a sua grande referência, embora, ao que conste, Aymont apresentasse espetáculo diferenciado do tradicional show de travestis).

Segundo Antônio, o Casanova exibia espetáculos desse tipo três vezes por semana, às quintas, sextas e sábados. Um cartaz escrito com lápis vermelho e verde trazia os nomes que formavam o elenco, algumas das quais ainda hoje desfrutam da admiração e do carinho de seu público: "o grande show O Mundo Encantado das Bonecas - Com René Rial - Fujika [de Halliday] - Alcina - Vera - Madame [Maria] Leopoldina - Marlene [Casanova] - E a atração internacional Lee Ribanchera - Direção musical de Sutt - Direção artística: Marlene [Casanova]." ${ }^{47}$ Às três ou quatro horas da manhã, continua João, as transformistas seguiam, às pressas, do Casanova para

os inferninhos de Copacabana (...) Os [sic] travestis da Boite Casanova serão talvez os mais ocupados do Rio de Janeiro e se apresentam na noite em dois, três pontos diferentes da Cidade. Esses artistas, bordando de canto e dança todo o show do Casanova, apresentam espetáculo medíocre, porém do ponto de vista humano de bastidor. É o espetáculo do espetáculo, com travestis jovens e velhos, cansados e enrugados, começando ou terminando carreira, luxuosamente vestidos, com uma variedade caríssima de perucas, jóias, appliques, adornos de um a um e meio mil cruzeiros antigos em cima dos corpos magros, que 
transitam no palco entre luzes indiretas e risinhos da platéia também medíocre. De feminilidade milimetrada em todos os pormenores, melindres, negaças e dengues, são esses os artistas da Lapa que mais comovidamente recebem os aplausos e, provavelmente, são eles os que mais vibram, na luta talvez mais dura de arrancar o seu pão da noite. ${ }^{48}$

Também no Casanova, Carlos Machado, o famoso produtor do teatro de revista, encenou seus espetáculos. ${ }^{49}$ Ali também Lennie Dale, bailarino estadunidense que havia vindo para o Brasil a convite do próprio Carlos Machado, estreia, em 1972, o primeiro show dos Dzi Croquetes (Gente computada igual a você) - o não menos famoso grupo de teatro que, com irreverência, criticava os signos e papéis estabelecidos aos gêneros, no auge repressivo da ditadura civil-militar. ${ }^{50}$ Naquele contexto de grandes contestações culturais, marcado, sobretudo, pelo Maio de 1968 francês, esse grupo teatral exercerá influência sobre vários artistas, como Os Secos e Molhados e Les Etóilles.

Com o mesmo nome de fantasia de Cabaré Casanova, o velho sobrado funcionou voltado ao público homossexual por mais de quatro décadas. Segundo relatos de antigos frequentadores, o público do Casanova agora era formado principalmente por homossexuais de baixo poder aquisitivo, embora também aparecessem, em menor contingente, jovens dos estratos médios que ali passavam antes de se dirigirem às boates da zona sul. As lésbicas também compareciam, mas sempre em número bastante reduzido, comparativamente aos viados. Em 2008 passa a apresentar shows para o público heterossexual, mas, tal como Viena-Budapeste, não tem vida longa. Após um tempo fechado, reabre como bar no andar térreo e voltado para a população boêmia que passou a frequentar a nova Lapa, surgida a partir do Polo Novo Rio Antigo, da Rua do Lavradio, nos primeiros anos do século XXI. Dionísio, antigo frequentador do local e blogueiro, afirma que o fechamento do Casanova como local GLS (sigla para Gays, Lésbicas e Simpatizantes, de apelo mais para socialização do que ativismo) guarda relação com o fim de um ciclo. ${ }^{51}$ Paradoxalmente, a revitalização da região trouxe mudanças no ambiente, que deixou de ser um gueto preponderantemente LGBT, para se constituir agora um "espaço descolado" (o "espaço heteróclito", na expressão de Brito Broca). Com efeito, as vitórias dos movimentos LGBTs neste Século, em termos de visibilidade e conquista de direitos, terminou por implicar, se não a extinção, pelo menos a ressignificação dos tradicionais territórios exclusivos existentes na cidade, dilema já antevisto por Pierre Bourdieu. ${ }^{52}$

As travestis com pendores artísticos puderam encontrar no Casanova empregabilidade, pertença e reconhecimento profissional. Por ali passaram ícones do mundo transformista, como Meime dos Brilhos (que trabalhou no seu palco por 35 anos), Fujika de Halliday (que, anos depois, integrou o elenco de 
Geórgia Bengston, uma das transformistas a conquistar grande reconhecimento pelo seu talento interpretativo, merecendo de Fernanda Montenegro o epíteto de "um dos maiores atores do Brasil") e a estrela maior da casa, Marlene, que terminou adotando como sobrenome artístico o nome do próprio Cabaré, Casanova. ${ }^{53}$ Outro espaço de entretenimento e sociabilidade dirigido ao público homossexual não é conhecido, até o momento, tão longevo no país quanto o Casanova. Foi sem dúvida o mais importante território de resistência de travestis, viados (depois autorreferidos como gays) e lésbicas, ao lado da Turma Ok e do Bifão Cabaré (este na Rua Santa Luzia, depois chamado de Boêmio, comandado pela impagável Laura de Vison, que também iniciou sua carreira artística no Casanova, como Laura Clayper). Enquanto o BifãoBoêmio atravessou as décadas de 1980 e 1990, encerrando suas atividades em 1998, a Turma Ok, constituída na década de 1960, saiu dos apartamentos de seus integrantes para ocupar espaço exclusivo também na Lapa, na década de 1980, e resiste até os dias atuais. ${ }^{54}$ Ali puderam se divertir, estabelecer redes de relações para além do ambiente, construir carreiras profissionais, desfrutar do sentimento de pertencimento, de aceitação, promovendo cuidado recíproco - mecanismos fundamentais para que pudessem fazer frente à precarização da autoestima decorrente do processo de estigmatização vivenciado..$^{55}$

Os atores transformistas (nomenclatura profissional oficializada pelo sindicato dos atores teatrais, na ocasião, para distingui-los, ao mesmo tempo, do antigo travestismo caricato, realizado por homens heterossexuais nas revistas e chanchadas, e das bichas travestidas que exerciam a prostituição, segundo depoimento de Cláudia Celeste) tanto apresentavam espetáculos inspirados no teatro de revista como shows musicais, com a intérprete cantando ou apenas fazendo a mímica da estrela representada (chamada de dublagem entre os nativos), mas sempre com o maior luxo possível, principalmente nos figurinos e perucas, como também destacou João Antônio. Os espetáculos na linha do teatro de revista, por apresentar elenco composto por bichas travestidas, passaram a ser designados pela imprensa também como teatro de bonecas. Suas apresentações não se restringiam aos inferninhos, como procura caracterizar o escritor João Antônio.

\section{O transformismo}

A profissão de transformista (travestismo artístico exercido por homossexuais masculinos) é um capítulo à parte na história dos territórios de resistência e memória de homossexuais e travestis na cidade do Rio de Janeiro. O registro mais remoto que até o momento se dispõe é dado por Madame Satã. Em 1928, com vinte e oito anos de idade, ele participa da Revista Loucos de Copacabana, encenada no Teatro Casa de Caboclo, na Praça Tiradentes. Faz a personagem Mulata do Balacochê, onde canta o samba Mulher de Besteira. ${ }^{56}$ 
Em 1938, ganha um importante concurso de fantasias no Teatro República, situado na Avenida Gomes Freire, no Centro (próximo à Praça Tiradentes e à Lapa). ${ }^{57}$ Esse concurso havia sido organizado pelo bloco carnavalesco Caçadores de Veados, constituído em 1930 por Antônio Setta (que, travestido, assumia o nome artístico de Rainha) e se tornara um evento que "atraía turistas de todas as partes do Brasil e de países estrangeiros. Todos aplaudiam muito e as bichas concorrentes ganhavam prêmios bons e retratos em alguns jornais e iam ficando famosas". ${ }^{58}$ Possivelmente seja o mesmo concurso que, segundo James Green, Dercy Gonçalves teria sugerido e que viria a se tornar um retumbante sucesso, sendo institucionalizado entre os festejos carnavalescos, ao ponto de, em 1951, receber subvenção pública para a sua realização. ${ }^{59}$ Satã ainda participaria em mais três edições seguintes, embora a ditadura do Estado Novo (1937-1945) estivesse em pleno vigor. ${ }^{60}$ Paradoxalmente, porém, em fins dos anos de 1940, os homossexuais ampliam a sua presença nos bailes de carnaval realizados nos teatros do entorno da Praça Tiradentes. Em 1956, já são vários os bailes de travestis espalhados pela Cidade, apresentando grande sofisticação. ${ }^{61}$ Em 1959, o do Teatro João Caetano (Baile dos Enxutos) já é conhecido internacionalmente. ${ }^{62}$ Essa popularidade durante o carnaval, no entanto, não os tornavam livres da violência usualmente desferida pela polícia e mencionada por Madame Satã a ocorrer nos anos de 1930. ${ }^{63}$ James Green, a partir de seus entrevistados, informa que, em 1962, o chefe de polícia do Rio de Janeiro teria proibido o uso de "fantasias de travesti" e, no carnaval de 1964, a Polícia "agredia com golpes de cassetetes quem tentasse entrar no Teatro Recreio", onde se realizava o baile do bloco Caçadores de Veados. ${ }^{64} \mathrm{Eu}$ localizei a Portaria ${ }^{\circ}$ 148, de 09/02/1960, do Chefe de Polícia, Coronel Ignácio Jacques Júnior, regulamentando os festejos de carnaval, na qual estabelecia a proibição, "em locais públicos ou privados", do "uso de fantasias e 'travesti' que atentem contra a moral e o decoro da família ou possam chocar a opinião pública". Também estavam proibidos "a formação de cordões (trens) nos salões de bailes, bem como o gênero de música conhecido por 'rock n'roll'" . ${ }^{65}-\mathrm{Ou}$ seja, quatro anos antes de consumado o golpe civil-militar. Em 22/08/1972, participando como a principal atração do espetáculo Misto Quente, em cartaz no Teatro Princesa Isabel, Valéria teve o nariz fraturado por socos desferidos por um motorista de táxi, durante uma corrida à tarde, da Urca à Glória, passando pela Lapa, após ela haver repudiado as suas investidas sexuais e "propostas indecorosas". ${ }^{66}$

Em 1951, Satã retorna ao teatro de revista, numa breve temporada, imitando Carmen Miranda. ${ }^{67}$ Em 1953, os produtores de espetáculos Walter Pinto e Carlos Machado (os maiores da cidade) exibem em seus shows uma belíssima travesti, apresentada como "vedette" de Paris. Ivaná (também grafado Ivana) ou Ivan Monteiro Damião, francês filho de pais portugueses, "é a primeira estrela transformista". ${ }^{68}$ Ivaná estréia no Teatro Recreio com a 
Revista É Fogo na Jaca, escrita por Freire Júnior, Luis Iglesias e Valter Pinto, ao lado de grande elenco, como ela, importado de Paris. No dia 04 de abril de 1953, a coluna Teatro, do jornal Correio da Manhã, noticia: "SÃO HOMENS AS DUAS 'estreias' que Valter Pinto importou de Paris. [...] Trata-se de Ivana e Zambelá, apresentadas como "famosas nos cabarés de Paris, sendo que Zambelá é estrela de um 'nightclub' (sic) há sete anos consecutivos". ${ }^{69}$ Valter Pinto, produtor do espetáculo, trouxera de Paris, contratadas para a revista, "o bailarino Leo Lauer, a 'vedette' Ivana e um grupo numeroso de coristas francesas". ${ }^{70} \mathrm{O}$ sucesso da revista é inigualável, passando de cem apresentações. Em agosto já é anunciada a participação de Ivana no show de Carlos Machado (autoria, concepção e direção), Cherchez La Femme, na Boite Casablanca. Descrito como "um SHOW que se iguala aos MELHORES espetáculos de PARIS-HUMOR, SEX-APPEAL e beleza no novo SHOW de MONTE CARLO!" (uma boate da Gávea que comemorava, com o espetáculo, o seu quinto aniversário) e a "consagração de Ivana e de Grande Otelo", traz pela primeira vez uma foto de Ivaná como Ivan. ${ }^{71}$ Ela também participa da Semana do Teatro, na série de eventos programados pela Casa dos Artistas, pela passagem do seu $35^{\circ}$ aniversário de fundação, no Teatro João Caetano, ao lado de nomes como Ankito, Aracy Cortes, Bibi Ferreira, Carlos Galhardo, Chocolate, Dercy Gonçalves, Gordurinha, Grande Otelo... ${ }^{72}$ Parece ter sido o único, em termos dos homossexuais que fizeram o travesti, a ter o seu talendo reconhecido, sem que fosse eclipsado pela categoria travesti, até o advento da crítica reconhecendo o trabalho de Geórgia. ${ }^{73}$ Até onde me foi possível avançar com as pesquisas neste momento, Ivaná não foi referida em nenhuma das matérias como travesti - atração, estrela, "vedette" eram os adjetivos com que a ela se referiam. Seja pelo fato de aqui haver sido apresentada como "estrela do Carroussel de Paris", seja pelo seu talento especial para representar o "belo sexo", o fato é que se chegou a sugerir que ela abrisse uma "escola para futuras 'vedettes' do nosso teatro musicado, pois sabe andar com uma graça rara e muita elegância"..."74

Em 1963, visita a cidade a primeira estrela transexual - Coccinelli, uma vedete francesa lindíssima que, após operada, adotara o nome de Jacqueline Deufresnoy (anteriormente Jacques Charles, um recruta do exército francês). Ela causa furor entre os homens heterossexuais e as bichas que também sonhavam se transicionar, ao posar de biquíni na piscina do Copacabana Palace, "com aqueles peitos enormes e tornando-se capa da Manchete". ${ }^{75} \mathrm{Em}$ 1964 aparecem as primeiras transformistas nacionais: Divina Valéria (Valter Fernandes Gonzáles, 21 anos de idade), nos shows The International Set e Les Girls, de 1964, na Boate Stop, na Galeria Alaska; e, em 1966, no Le Boys, levado nos palcos do Teatro Brigite Blair - "o mais luxuoso show de travestis", segundo o programa do espetáculo. ${ }^{76}$ Em 1966, Valéria grava um compacto pela Mocambo, contendo um pot-pourri de sambas (Batucada de Bamba, Rancho da 
Praça Onze, Procissão, ...) e outras músicas. O título do compacto é: Valéria, $O$ Travesti. Na capa, duas fotos, uma como mulher, outra como homem. $\mathrm{Na}$ parte de baixo da capa, a inscrição, em letras vermelhas: "Interpreta 'Les Girls' e "The International Set"'.

Por essa época, o termo travesti no mundo dos espetáculos ainda significava o ato de vestir-se e imitar o outro gênero, recurso teatral empregado em vários países para contornar a proibição de mulheres atuarem no teatro. Embora já houvesse a associação da ambiguidade ou inversão do gênero, praticada maciçamente nos bailes de carnaval dos teatros Recreio e João Caetano, com a homossexualidade. ${ }^{77}$ Havia, pode-se dizer, dois tipos distintos de travestis (ou "fazer travesti", como era usual dizer na ocasião), em nossas artes cênicas, casas noturnas, cinema e no carnaval: homens heterossexuais fazendo a representação do feminino em forma de paródia, (do que Oscarito e Grande Otelo são as expressões máximas, popularizadas através do cinema); e, também, mulheres (em muito menor número), no carnaval e no teatro (aqui não tão frequentemente burlesca quanto aqueles), sem vinculação necessária à homossexualidade; e, igualmente no teatro, em boates e no carnaval, homens então designados como homossexuais (hoje transgêneros), portadores de estilo de gênero dito efeminado (bichas, na terminologia popular; invertidos, anormais, pervertidos, bonecas e enxutos, no dizer da imprensa). Essas pessoas, então designadas pelo pronome masculino, não se apresentavam com o gênero feminino para os atos cotidianos da vida civil; mesmo na ida para o teatro ou boate, onde apresentariam os seus shows. Montavam-se e desmontavam-se (como costumam dizer ainda hoje) no local da apresentação.

Pelo exame das sessões de espetáculos, publicadas em periódicos de grande circulação na cidade e dos relatos dos memorialistas da Lapa, parece que é entre 1964 e 1972, com o aumento da presença das bichas que, nos palcos, interpretavam o gênero feminino de forma, digamos, mais supostamente natural, fora do registro da paródia, aquilo que originariamente designara um recurso cênico vai adquirindo conotação identitária, graças à ação nomeadora de jornalistas. Incorporar o outro gênero, à perfeição, ou nem tanto, nas ruas (as mais ousadas) e/ou profissionalmente, vai se transmutando numa nova modalidade de ser. Seus dois maiores expoentes, Valéria e Rogéria, são designadas pela imprensa não como atores, cantores, dançarinos, mas como "o travesti”. Ao que parece, tornam-se "o próprio travesti”, segundo a talvez inaugural expressão de Gilberto Souto, ao se referir ao talento do ator estadunidense Julian Eltinge "para bem imitar o sexo feminino". Essa negativa de reconhecimento, a escassa referência através da atividade profissional, como os/as demais profissionais (ator / atriz, cantor / cantora, bailarino / bailarina), reduzindo-as todas na categoria - agora identidade - travesti, parece imprimir u'a marca profunda em suas subjetividades. Essa cesura em sua autoestima profissional, aliada ao estigma atribuído à homossexualidade (na verdade transexualidade), 
parece levar essas artistas a se mostrarem sempre grandiosas, exuberantes, uma oitava acima... Não raro encontramos vestígios da necessidade de afirmação, da busca por reconhecimento em suas falas. Valéria, por exemplo, na entrevista para a matéria que anuncia a estreia do espetáculo Misto Quente no Teatro Princesa Isabel, em Copacabana, no segundo semestre de 1972, diz de si:

Eu vou acontecer de uma maneira que nenhuma atriz jamais aconteceu. Eu consegui reunir em um só show o trabalho dos três grandes figurinistas brasileiros, Denner, Guilherme Guimarães e Clodovil, sem falar, é claro, de algumas roupas maravilhosas que trouxe da Europa. Tenho muita confiança neste trabalho pois em hipótese alguma, depois de meu sucesso na Europa e atualmente no Monsieur Pujol, aceitaria fazer espetáculo que fosse me desvalorizar. ${ }^{78}$

A marca maior do reconhecimento artístico que se denota vir de parte dos jornalistas, ao falarem ou simplesmente apresentarem o programa do espetáculo em que essas profissionais atuam, parece ser não lhes designar com essa nova identidade: apresentar-lhes simplesmente o nome artístico e, vez por outra, mencionar suas habilidades - cantora, atriz... ou, no exemplo de Rogéria, "o versatilíssimo travesti que se tornou na grande vedeta da noite carioca". ${ }^{9}$ Ainda que, três meses depois, decerto no quadro da estratégia mercadológica, no cartaz contratado pela produção para publicar no jornal, apareça como: "a enxutérrima Rogéria", "o mais famoso travesti do Brasil", junto com "as 20 mais badalativas 'bonecas' do Rio num show divertido e invertido". ${ }^{80}$

No entanto, em seu trabalho de memória, Rogéria, em entrevista algo recente a um sítio na internet (lamentavelmente sem a data da postagem), declara:

Hoje em dia, eu agradeço especialmente aos jornalistas que publicaram em 64, junto com a Revolução, a seguinte manchete: "Surge uma nova estrela". Essa manchete impediu que eu fosse expulsa. Eu não surgi como um homem vestido de mulher, surgi como um grande artista porque eu já era maquiador da TV Rio. Lá eu já maquiava todas as mulheres famosas que viviam dizendo pra eu ir pro palco. ... Se o meu show fosse uma coisa de bichice, nós seríamos retiradas. ${ }^{81}$

Segundo as narrativas de Cláudia Celeste, Suzy Parker e Valéria, será em 1964, através dos espetáculos Rio à Noite, nas boates Alcatraz (Copacabana) e Oásis (Leblon), e The International Set e Les Girls, na Boate Stop (mais tarde Sótão), na Galeria Alaska, em Copacabana, que terão início as carreiras de transformistas. Essa galeria tornar-se-á, a partir da década de 1960 e até 
pelo menos a década de 1980, o território entendido por excelência, havendo quem afirmasse ser "o maior reduto gay do país". Situada no Posto Seis de Copacabana, foi mencionada (diretamente ou pelos bares de seu entorno) em canções compostas por Agnaldo Timóteo e por Ângela Rô Rô. Daquele, a balada A Galeria do Amor (cujo título original era exatamente Galeria Alaska), faixa-título de seu LP lançado em 1975, onde se pode verificar o emprego do termo entendido como palavra-código: "Numa noite de insônia saí / procurando emoções diferentes / e depois de algum tempo parei / curioso por certo ambiente / onde muitos tentavam encontrar / o amor numa troca de olhar... / na galeria do amor é assim / muita gente à procura de gente / a galeria do amor é assim / um lugar de emoções diferentes onde a gente que é gente se entende / onde pode se amar livremente...". ${ }^{82}$ Desta, a Balada da Arrasada, lançada no LP Ângela Ro Ro, Polygram, 1979, onde menciona dois bares da região - Samir e Acapulco: "Entregou-se sem um zelo ao apelo de sorrir / Ofertou-se inteira e dócil a um fácil seduzir / Sem saber que o destino diz verdades ao mentir / Doce ilusão do amor... / Doce ilusão do amor... // Arrasada, acabada, maltratada, torturada / Desprezada, liquidada, sem estrada pra fugir / Tenho pena da pequena que no amor foi se iludir / Tadinha dela... / Tadinha dela... // Hoje vive biritada sem ter nem onde cair / Do Acapulco à calçada ou em frente ao Samir / Ela busca toda noite algo pra se divertir / Mas não encontra, não... / Mas não encontra, não... // Desespera dessa espera por alguém pra lhe ouvir / Sente um frio na costela e uma ânsia de sumir / Transa modelito forte, comprimidos pra dormir / E não acorda mais... / E não acorda mais..."

Segundo Valéria, a ideia de montar um espetáculo apenas com travestis teria partido de pessoas do meio artístico que trabalhavam na televisão Canal Rio, que elas conheceram frequentando os programas de auditório dessa emissora. ${ }^{83} \mathrm{O}$ espaço viabilizado foi o da Boite Stop, que no momento atravessava problemas financeiros. Foi encenado o espetáculo The International Set, com grande sucesso. ${ }^{84}$ No elenco havia onze (11) travestis. A boa recepção deu ensejo à montagem do segundo. No dia 04/10/1964, a coluna Zumzum, da Revista de Domingo do Jornal do Brasil anuncia a estreia de Le Girls para novembro. Nenhuma referência sobre o tipo de espetáculo. Passou todo o mês e nada.

No domingo vinte e nove de novembro, o Jornal do Brasil publicou matéria com destaque e detalhe (no topo da coluna externa de página ímpar - 35 -, primeiro caderno), anunciando a reabertura da casa com o show Les Girls, para o dia quatro de dezembro, completamente remodelada, com os seus 130 lugares. $\mathrm{O}$ anúncio foi feito dentro do que me pareceu uma estratégia para se antecipar e neutralizar eventuais ações da Censura na sua inviabilização, bem como atrair a atenção e a simpatia das camadas altas da sociedade carioca, principalmente suas mulheres. Com o título "Stop Clube dá renda a asilo", a reportagem anunciava que as rendas da estreia e do couvert de uma noite por 
mês seriam destinados a instituições "de caridade", indicadas pelo Serviço de Utilidade Pública do Jornal do Brasil. Com direção de Luís Haroldo, texto de Mário Meira Guimarães, música de Roberto Kelly "e orquestra dirigida pelo Maestro Bahia", o elenco foi assim divulgado: "é integrado por Jardel Melo, cedido especialmente pela Televisão Rio e mais Rogéria, Manon [que integrara o trio Les Coccinelles], Marquesa, Brigite, Carlos Gil, Jean-Jacques, Nádia [possivelmente a mesma Nadja de Les Coccinelles], Vanda, Jerry de Marco, e Carmem". Para o espetáculo, oito perucas foram importadas dos EUA; o guarda-roupa tinha a assinatura do figurinista Viriato Ferreira e estava orçado em 15 milhões de cruzeiros; a coreografia de autoria de Djalma Brasil; e a cenografia, de Ricardo. Nada é antecipado sobre o tipo de espetáculo. ${ }^{85}$ No dia cinco de dezembro, outra vez no Primeiro Caderno, página ímpar, coluna externa, uma segunda matéria trata da reabertura da boate, anunciando outra vez que a renda da estreia será destinada a instituição de caridade: "Stop Club reabre hoje com 'Les Girls' e destina renda da estréia a asilo". Outra vez nenhuma informação quanto ao estilo do espetáculo. A referência a espetáculo de travestis somente se dará na edição de 09/03/1965.86

A estratégia surtiu efeito. Na edição do $J B$ da quarta-feira, dia 09/12/1964, $1^{\circ}$ Caderno, p. 9, coluna externa, vê-se uma foto com uma freira, duas jovens estudantes uniformizadas, outra mulher e dois homens de terno. Acima, a legenda, em caixa alta: "O papel da caridade". Abaixo da foto, a notícia da entrega do valor apurado na estreia para a Escola Nossa Senhora do Carmo, dirigida pelas Irmãs Vicentinas. Foi arrecadado meio milhão de cruzeiros, capaz de garantir o custeio dos estudos de mais de 200 meninas, em regime de internato, por todo um ano letivo. No primeiro domingo de cada mês, todo o couvert apurado será também doado para a mesma instituição. Agradecida, a irmã superiora Rosina conclamou os outros empresários a fazerem o mesmo, "porque o que importa é o gesto e os resultados positivos na educação dos jovens que serão beneficiados por ele". O último parágrafo dá o fechamento alvissareiro: "Prestigiando a estréia com renda beneficente, compareceram, entre outros," e passa a elencar nomes de personalidades de referência na alta sociedade carioca - nomes como o dos casais Oscar Bloch, Antonio Gallotti, Aristides Garnier...

Os espetáculos de travestis ou bonecas (musicais e revistas) vão se impondo nos espaços culturais da cidade, desbancando as mulheres. Para Suzy, a preferência dos produtores em escalar as transformistas no lugar das mulheres talvez guardasse relação com o esmero exibido por elas na representação do feminino e o desinteresse das mulheres para aquele estilo de teatro ${ }^{87} \mathrm{Eu}$ acrescentaria que a grande atração possivelmente não se limitasse à extraordinária qualidade da representação do feminino, mas, sobretudo, ao estilo de feminino invariavelmente incorporado por elas: glamoroso e sedutor (o "sex-appeal" referido pelo jornalista), conformando o padrão fêmea fatal 
utilizado por atrizes estadunidenses como Betty Davis e Marilyn Monroe, a realçar ainda mais o apelo do exótico. Sem dúvida, ao lado do efetivo talento das transformistas, o exotismo que envolvia a travestilidade, sobretudo quando patente o apuro exibido na representação desse feminino, com belos rostos e corpos esguios, tornava esses espetáculos um atrativo excepcional, no quadro das dificuldades gerais por que passava o teatro de revistas, frente à televisão e ao cinema, naqueles tempos de intensas transformações, nos campos político e cultural, no Brasil e no mundo ocidental.

É precisamente nesse contexto marcado por grandes transformações que as bichas dotadas de habilidades cênicas, referidas pela sociedade de bem como "indivíduos anormais", "invertidos do amor", "pederastas" ou homossexuais, saberão aproveitar as oportunidades, construindo suas carreiras, ainda que em um circuito cultural de segunda linha, no contexto da indústria de entretenimento.

Outro território conquistado pelas transformistas na década de 1960 foi o Cabaré Brasil Dourado. João Antônio registra a casa noturna como localizada na Rua Visconde de Maranguape, enquanto outros memorialistas fazem referência à Rua da Lapa (prolongamento daquela), no número $10 .{ }^{88}$ Citando Ronaldo Crespo como "diretor de travestis" e dotado de "brilho criador", ele descreve o local como o "domínio de travestis que envolviam tudo com muita propriedade e sensivelmente. ${ }^{89}$ Suzy Parker recorda que, em 1964, atuaram no Brasil Dourado as travestis: Ira Velasquez, Vanja (de Nova Iguaçu), Jacqueline de Bois, Daniela, Mileny, Eli Jones e Renata Crespo, a atriz principal (persona de Ronaldo Crespo, produtor de shows, quando montado). Seguem-se diversos outros espetáculos, em boates e em teatros, como o Dulcina e o Rival, ambos na Cinelândia, e o Carlos Gomes, na Praça Tiradentes, estrelados por Jane Di Castro.

Em 1969, Rogéria e Valéria vão para Paris. Espalhada a notícia da abertura desse novo e promissor campo de trabalho, aliada à exacerbação moralista e censória no curso da ditadura civil-militar, nesse ano tem-se um êxodo de travestis - seja para os palcos, seja para as esquinas de diversas cidades da Europa (França, Itália, Espanha, Alemanha, Suécia). Trabalham como transformistas e como prostitutas e, às vezes, as duas atividades podiam ser exercidas ao mesmo tempo, o que não é incorporado pelas narrativas constitutivas de suas trajetórias oficiais. A exposição noturna sensualíssima por elas realizada as punha em contato com uma infinidade de cavalheiros seduzidos, desejosos, apaixonados, dispostos a tudo para desfrutar dos prazeres apenas sugeridos nos palcos... O que não significa necessariamente a troca de sexo por dinheiro, mas, também, por presentes, noitadas, passeios.

Há quem atribua essa emigração em massa de travestis brasileiros, de um lado, à facilidade que encontraram para ganhar dinheiro, contando inclusive com um relativo respeito por parte de clientes e da polícia. ${ }^{90}$ De outro, 
à possibilidade de atuar em palcos estrangeiros e aos sucessivos desconfortos $\mathrm{e}$ entraves que passaram a ser submetidas as produções - encaminhamento prévio do roteiro à Divisão de Censura de Diversões Públicas para avaliação, visitas de censores aos ensaios e às funções, ingerências nos textos e encenações. Esta é a opinião, por exemplo, de Cláudia Celeste. ${ }^{91}$

Segundo os relatos de Suzy Parker e Ieda Brown, entretanto, o aprofundamento da ditadura não fez cessar esses espetáculos. Elas atuaram no Rio, São Paulo e em Belo Horizonte, onde ocuparam palcos consagrados pela tradicional família mineira, como as boates Kaverna e Sukata, indo depois para o Uruguai e a Argentina. ${ }^{92}$ Ambas confirmam a obrigatoriedade da submissão dos textos (e, em alguns casos, das encenações) previamente aos censores, mas em casos de censura, recorriam ao capital social constituído a partir da plateia que já as acompanhava pelos diversos trabalhos realizados - várias daquelas senhoras da sociedade que as prestigiavam conheciam alguém influente que pudesse facilitar a liberação do espetáculo. Outro estratagema era apresentar um espetáculo para o Censor e outro para a plateia. Mas em geral, dizem, a Censura não incomodava muito, na medida em que viam as suas produções como de insignificante potencial de ameaça à conjuntura política. Os fatos noticiados nos periódicos da época parecem não confirmar esta memória, contudo.

Curiosamente, no ano de 1972, que é quando ocorre a expulsão expressa dos homossexuais da televisão (Denner, Clodovil e Clóvis Bornay sendo os mais famosos), determinada pelos órgãos de censura de diversões, verifica-se significativo retorno das transformistas: Valéria volta e estreia, em julho daquele ano, o espetáculo Misto Quente, no Teatro Princesa Isabel. No elenco estão o humorista Agildo Ribeiro, o pianista Pedrinho Mattar e o conjunto musical Os Brasões. O texto tem a assinatura de Miele e Bôscoli, a direção é de Augusto César Vanucci e os figurinos são do múltiplo e reconhecido artista plástico Juarez Machado.

Em 07/09/1973, Rogéria retorna de Paris para encenar show de Carlos Machado com texto e música de Sérgio Porto (Stanislaw Ponte Preta), na boate Erótica. Não teve sucesso, porém: a Censura vetou. ${ }^{93}$ Tenta estrear com o espetáculo Por via das dúvidas (ou por dúvidas das vias), com direção de Agildo Ribeiro, e texto de Max Nunes e Haroldo Barbosa, no Teatro Princesa Isabel. Novos entraves com a Censura, inclusive com cancelamento após liberação e estando já todos os ingressos vendidos - prometido o lançamento para 27/09/73, só conseguiu estrear no dia 20/10/73. ${ }^{94}$ Também em 1973, entra em cartaz $O$ Mundo é das bonecas, com texto de Ângela Leal e produção de seu pai, Américo Leal, exibido no Teatro Rival, trazendo apenas a categorização de que se trata de "espetáculo de travestis", sem menção do nome de nenhuma integrante. ${ }^{95}$ O boom do transformismo ocupará palcos em teatros, casas de espetáculos e boates, no Centro, na Praça Mauá e em Copacabana, em casas como Barbarela, na Rua Prado Júnior, com balé de Denis Duarte; o Tamariz, também na Prado 
Júnior; o Balalaica, na Rua Siqueira Campos (onde atualmente funciona um supermercado); o Pigalle, no Posto 6, na Avenida Atlântica - "uma casa fina, sem prostituição". .96

Em 1982, Geórgia Bengston, das poucas a conquistar reconhecimento pelo seu talento dramático, parte para conquistar novos territórios e ocupa o palco do Teatro de 400 lugares do SESC de São João de Meriti, na Baixada Fluminense, região dormitório periférica à Capital. No elenco estão Fujika de Halliday e Nórika Heiner, entre outras. Geórgia renova e ao mesmo tempo recupera o Teatro de Revista, juntando humor à crítica sarcástica das injustiças sociais e políticas estruturantes da sociedade brasileira. Tem a casa lotada todas as noites, às sextas, aos sábados e domingos, naquela região de escassas ofertas culturais, habitada por trabalhadores de camadas mais populares, eles que, no passado, foram o público majoritário das Revistas de Ano. ${ }^{97}$

\section{Considerações finais}

Como procurei mostrar, para além dos processos higienistas e segregadores levados a efeito de tempos em tempos pelos diversos níveis de poder e controle da cidade do Rio de Janeiro, nas praças, parques, mictórios, hospedagens, conventilhos, nos bailes de carnaval, nos palcos dos cabarés, dos shows musicais e dos teatros, nas plateias dos concursos de Misses e protagonizando suas paródias, nos programas de auditório das emissoras radiofônicas, nos fã-clubes das cantoras Emilinha e Marlene, em todos esses espaços, sodomitas, bagaxas, pederastas, invertidos do amor, bonecas, travestis, transformistas e homossexuais masculinos, com astúcia e criatividade, souberam se contrapor aos processos de estigmatização a eles dirigidos e constituir seus próprios espaços de sociabilidade, sexo, expressão cultural e carreiras profissionais, fazendo surgir vínculos de identificação, pertença, apoio mútuo, tornando-os territórios de resistência e memória, alguns dos quais chegaram até a primeira década do século XXI ou ainda atuando nos dias atuais, como o Cabaré Casanova e a Turma Ok.

\section{NOTAS}

1 CERTEAU, Michel de. A Invenção do Cotidiano. Artes de Fazer. $9^{\mathrm{a}}$ edição. Rio de Janeiro: Vozes, 2003.

2 Emprego o termo no sentido consagrado pela moderna geografia, que é o de espaço apropriado individual ou coletivamente a partir de relações de poder. SILVA, Jan Carlos da. O conceito de território na geografia e a territorialidade da prostituição. In: RIBEIRO, Miguel Ângelo e OLIVEIRA, Rafael da Silva. Território, sexo e prazer: olhares sobre o fenômeno da prostituição 
na geografia brasileira. Rio de Janeiro: GRAMMA, 2011, p. 19-41.

3 Ainda que até aproximadamente os anos de 1980 não houvesse clareza a respeito da orientação heterossexual das travestis, sendo essa categoria empregada como sinônimo de homossexual, assumo, neste artigo, a diferenciação que passaria a ser problematizada dos anos de 1990 em diante.

4 CHAUNCEY, George. Gay New York. 1994.

5 Expressões comportamentais, vocabulares e visuais distintas da cultura hegemônica, vinculadas a contextos específicos. O conceito teria principiado a ser utilizado na sociologia, em 1971, passando, depois, a ser empregado pela Escola de Chicago, no interior da teoria do desvio, e na Inglaterra, através da Escola de Birmingham, também na década de 1970. ARCE CORTES, Tania. Subcultura, contracultura, tribus urbanas y culturas juveniles: ¿homogenización o diferenciación?. Rev. argent. sociol., Buenos Aires, v. 6, n. 11, dic. 2008. Disponível em: $<$ http://www.scielo.org.ar/scielo.php?script=sci_arttext\&pid=S1669-

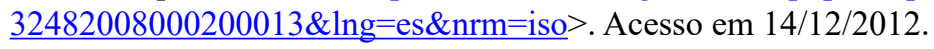

6 GOFFMAN, Erving. Estigma: notas sobre a manipulação da identidade deteriorada. [ $4^{\mathrm{a}}$ edição.] Rio de Janeiro: LTC, 1988.

7 GUIMARÃES, Carmem Dora. O Homossexual visto por entendidos. Rio de Janeiro: Garamond, 2004, p. 55-57.

8 MORANDO, Luiz. Paraíso das Maravilhas: Uma história do Crime do Parque. Belo Horizonte: Argumentum, 2008; GREEN, James N. Além do Carnaval. A homossexualidade masculina no Brasil do Século XX. São Paulo: Unesp, 2000; FIGARI, Carlos. @s outr@s cariocas. Interpelações, experiências e identidades homoeróticas no Rio de Janeiro. Séculos XVII ao XX. Belo Horizonte Rio de Janeiro: UFMG IUPERJ, 2007; COSTA, Rogério da Silva Martins da. Sociabilidade homoerótica masculina no Rio de Janeiro na década de 1960: relatos do jornal $O$ Snob [Dissertação]. FGV-CPDOC, Mestrado Profissional em Bens Culturais e Projetos Sociais, 2010.

9 SOARES, Luiz Carlos. Rameiras, ilhoas, polacas... A prostituição no Rio de Janeiro do século XIX. São Paulo: Ática, 1992. Agradeço a Claber Borges a indicação desse livro.

10 Levantamento realizado pelos membros do grupo Triângulo Rosa, RJ, em 1986. Acervo pessoal.

11 Em respeito às suas pessoais formas de identificação, as referências serão feitas sempre no feminino, registrando, contudo, que na ocasião empregava-se o masculino, inclusive elas próprias.

12 Na ocasião inexistia distinção entre homossexualidade e travestilidade, sendo vistas como sinônimas.

13 FIGARI, op. cit.

14 Depoimentos pessoais das artistas transformistas Suzy Parker e Cláudia Celeste, em várias ocasiões, integrantes do projeto de constituição de fontes audiovisuais da trajetória de vida dessas personagens, em andamento.

15 VAINFAS, Ronaldo. Trópicos dos Pecados - Moral, sexualidade e inquisição no Brasil. Rio de Janeiro: Nova Fronteira, 1997, p. 151.

16 A prostituição masculina era exercida pelos então chamados "bagaxas" - homens que prestavam serviços sexuais remunerados, tanto como ativos, quanto como passivos, segundo Luiz Carlos Soares (op. cit., p. 72); Mary Karasch, apoiada em Lassance Cunha, afirma que 
até 1845 a profissão de "mulher pública" era exercida apenas por escravas. KARASCH, Mary C. A vida dos escravos no Rio de Janeiro (1808-1850). São Paulo: Companhia das Letras, 2000, p. 286; PIRES DE ALMEIDA apud SOARES, 1992, p. 70.

17 BASSERMANN, Lujo. História da prostituição - Uma interpretação cultural. Rio de Janeiro: Civilização Brasileira, 1968, p. 132; VAINFAS, op. cit., p. 162; OLIVIERI, Achillo. Erotismo e grupos sociais em Veneza no século XVI: a cortesã. In: ARIĖS, Philippe e BÉJIN, André (orgs.). Sexualidades Ocidentais. São Paulo: Brasiliense, p. 115-120.

18 MACEDO apud SOARES, op. cit., p. 71.

19 SANTOS, Noronha. As Freguesias do Rio Antigo. Rio de Janeiro: O Cruzeiro, 1965; MACEDO apud SOARES, op. cit., p. 71. A exemplo do Campo da Aclamação, a prostituição era exercida também por mulheres nas Freguesias: do Sacramento (apenas de 1861 a 1872), de Santa Rita e Santo Antônio (tanto de 1861-1872 quanto de 1873 a 1905). Mattos a classifica como "Zona do Meretrício", em relação às mulheres. MATTOS, Rogério Botelho de. A Dinâmica dos espaços de prostituição na cidade do Rio de Janeiro: 1840-1940 in: RIBEIRO, Miguel Ângelo e OLIVEIRA, Rafael da Silva. Território, sexo e prazer: olhares sobre o fenômeno da prostituição na geografia brasileira. Rio de Janeiro: GRAMMA, 2011, p. 45-62.

20 KARASCH, Mary C. A vida dos escravos no Rio de Janeiro (1808-1850). São Paulo: Companhia das Letras, 2000.

21 Espaço de concentração de africanos, crioulos e pardos, escravos (alguns de ganho) ou libertos. Muitas ofereciam comida e bebida. A afluência dessa população terminava por produzir batuques, danças e cantorias. Também era definido como espécie de hospedaria barata e precária; tipo de alojamento temporário ou noturno para essa população. SOARES, Carlos Eugênio Líbano. Zungú: Rumor de muitas Vozes. Rio de Janeiro: Arquivo Público do Estado do Rio de Janeiro, 1998.

22 SOARES, op. cit., p. 50

23 VAINFAS, op. cit., p. 167; SOARES, op. cit., 1992, p. 74; CAMINHA, Adolfo. O Bom crioulo. SP: [1895] 2007, $7^{\mathrm{a}}$ edição, 102 p, p. 40.

24 CAMINHA, op. cit.

25 CAMINHA, op. cit., p. 40 e 46.

26 ALMEIDA apud SOARES, op. cit.

27 A sodomia era tão comum na Itália ao ponto de ficar conhecida, no século XV, como "vício italiano". Na França, abundante junto à Corte nos séculos XVI e XVII, recebeu os nomes de "italianização da França", "vício francês" e "belo vício", vez que percebida como traço de distinção entre os cortesões, embora violentamente reprimida nos meios populares. VAINFAS, op.cit., p. 162-163.

28 VAINFAS, op. cit., p. 164.

29 ALMEIDA apud SOARES, 2011, p. 79. Largo de São Domingos, Campo do Rosário ou da Lampadosa, ia "do Morro de Santo Antônio ao da Conceição, até o futuro Campo de Sant'Ana, nos limites do mangue de São Diogo" GERSON, Brasil. História das ruas do Rio. Rio de Janeiro: Lacerda, 2000, p. 124. O Rocio Grande (mais tarde Praça Tiradentes) foi dele desmembrado em 1721 (Idem, p. 112).

30 Lupanar, alcoice. F. Convento. Reunião de muitas pessoas que vivem em comum (AULETE, 1964, p. 937).

31 GERSON, op. cit., p. 214 
32 No Campo de Santana, a prostituição era também exercida por mulheres. Mattos a classifica, no período de 1840-1860, como prostitutas "de segunda ordem", "constituídas, em sua maioria, por negras ou açorianas que eram visitadas por homens das classes remediadas da sociedade" (2011, p. 48). No período de 1861 a 1872, eram classificadas como integrantes da "Zona do Meretrício", uma classificação intermediária entre a "alta" e o "baixo meretrício", com mulheres "mais novas e refinadas, constituídas, em sua maioria, por 'ilhoas' jovens e sadias, que desenvolviam suas atividades em 'pensões', hotéis aristocráticos e casas de espetáculos sofisticadas, como os teatros Phenix Dramática e Café Cantant" (MATTOS, op. cit., p. 48, 6162). Luiz Carlos Soares, de seu turno, apoiado na tese do médico Lassance Cunha, apresentada em 1845, classificava-as como "mulheres públicas de segunda ordem", com o mesmo conjunto étnico: "em sua maioria negras ou portuguesas vindas dos Açores". SOARES, op. cit., p. 27.

33 SOARES, op. cit., p. 72.

34 DAMATA, Gasparino. Antologia da Lapa. Vida boêmia no Rio de ontem. Rio de Janeiro: Codecri, 1965, p. 16-18.

35 CAVALCANTI, Di. A Lapa dos meus vinte anos. In: DAMATA, Gasparino. Op. cit., p. 46 36 MARTINS, MARTINS, Luís. Noturno da Lapa. Rio de Janeiro: Civilização Brasileira, 1964 , p. 24

37 A um tempo identidade e palavra-código. Ver: RODRIGUES, Rita. Dicionário Crítico de Gênero. Dourados: UFGD, 2015, p. 193.

38 BROCA, Brito. A Lapa: Ontem e hoje. In: DAMATA, Gasparino. Op. cit., p. 26.

39 MARTINS, op. cit., p. 60.

40 BROCA, op. cit., p. 26.

41 BROCA, op. cit., 26-27.

42 MARTINS, op. cit., p. 103.

43 HOLANDA, Nestor, op. cit., p. 166, nota 55.

44 SILVA, Aguinaldo. Memórias da Guerra. In: DAMATA, Gasparino. Op. cit., p. 256.

45 A primeira edição de Malagueta, Perus e Bacanaço, onde consta o A Lapa acordada para morrer, é de 1963, pela Civilização Brasileira, cf. LUSTOSA, Isabel (org.). Lapa do Desterro e do Desvario - Uma antologia. Rio de Janeiro: Casa da Palavra, 2001.

46 ANTÔNIO, João. A Lapa Acordada para Morrer. In: LUSTOSA, Isabel. Lapa do desterro e do desvario: uma antologia. Rio de Janeiro: Casa da Palavra, 2001, p. 229-230.

47 Id. Ibid, p. 230

48 ANTÔNIO, op. cit., p. 231

49 Revista era um tipo de peça teatral burlesca, leve, com críticas sociais e políticas. VENEZIANO, Neyde. O Teatro de Revista no Brasil - Dramaturgia e convenções. São Paulo: SESI-SP Editora, 2013. Sobre Carlos Machado no Casanova: DIONÍSIO. Velho Casanova... In: Alterblog, 14/09/2008. Disponível em: http://dionisio-alterblog.blogspot.com.br/2008/09/ casanova-confesso-que-o-fim-do-cabar.html. Acessos em: 17/09/2014 e 13/05/2016.

50 WIKIDANCA.NET. Dzi Croquetes. Disponível em: http://www.wikidanca.net/wiki/index. php/Dzi_Croquettes. Acesso em: 17/09/2014.

51 DIONÍSIO, op. cit. 
52 BOURDIEU, Pierre. A dominação masculina. Rio de Janeiro: 2007, p. 143-149. Ver por exemplo: Buraco da Lacraia.

53 http://www.vcvai.com/rio-de-janeiro/cabaret-casa-nova. Acesso: 17/09/2014; BASTOS, José Fernando. Quando as bichas fazem o "show". In: Lampião da Esquina, ano 3, n 36, maio de 1981, p. 17.

54 DIONÍSIO, op. cit.; SOLIVA, op. cit.

55GOFFMAN, Erving. Estigma: notas sobre a manipulação da identidade deteriorada. [ $4^{\mathrm{a}}$ edição.] Rio de Janeiro: LTC, 1988.

56 DURST, Rogério. Madame Satã $\square$ Com o diabo no corpo. Coleção Encanto Radical. São Paulo: Brasiliense, 1985, p. 16. Madame Satã jamais adotou identidade de gênero feminina.

57 Localizava-se no $n^{\circ}$ 82, atual 474, onde hoje se encontra o estúdio da TV Brasil. Cf. Centro Técnico de artes Cênicas, http://www.ctac.gov.br/centrohistorico/TeatroXPeriodo. asp? $\operatorname{cod}=138 \& \mathrm{cdP}=21$, acesso em 18/10/2014.

58 PAEZZO, op. cit., p. 59.

59 DURST, op. cit., p. 27 e GREEN, op. cit., p. 340; GREEN, op. cit., p. 252, 332, 334-346.

60 PAEZZO, op. cit. p. 59; DURST, op. cit., p. 27.

61 GREEN, op. cit., p. 352.

62 GREEN, op. cit., p. 360.

63 PAEZZO, op. cit., passim.

64 GREEN, op. cit., p. 363, 386.

65 Correio da Manhã, 11/02/1960, $1^{\circ}$ Caderno, p. 5; 27/02/1960, $2^{\circ}$ Caderno, p. 6.

66 Jornal do Brasil, 23/08/1972, $1^{\circ}$ Caderno, p. 24.

67 DURST, op. cit., p. 72.

68 GREEN, op. cit., p. 388; e CELESTE, entrevistas pessoais concedidas de 19 a 22 de junho de 2014.

69 Correio da Manhã, 02/04/1953, $1^{\circ}$ Caderno, p. 9, Coluna Teatro.

70 Correio da manhã, 09/04/1953, $1^{\circ}$ Caderno, p. 11.

71 Correio da Manhã, 14/08/1953, $2^{\circ}$ Caderno, p. 3.

72 Correio da Manhã, 21/08/1953, $1^{\circ}$ Caderno, p. 9.

73 BASTOS, José Fernando. Quando as bichas fazem o "show". In: Lampião da Esquina, ano $3, \mathrm{n}^{\circ}$ 36, maio de 1981, p. 17.

74 Correio da Manhã, 05/06/1953, $1^{\circ}$ Caderno, p. 7, Coluna Ronda.

75 GREEN, op. cit., p. 372; CELESTE, idem, 2013 [2014]. Assumo os termos autorreferidos pelas informantes. Recorde-se que na época não havia a clara categorização da transexualidade, como a temos na atualidade.

76 CELESTE, idem, 2014.

77 GREEN, op. cit.

78 Jornal do Brasil, Revista de Domingo, 16/07/1972, sem referência de página. 
79 Jornal do Brasil, Caderno B, terça-feira, 03/01/1967, p. 4.

80 Anúncio no Jornal do Brasil de sábado, 15/04/1967, $1^{\circ}$ caderno, p. 15: espetáculo Vem Quente que Estou Fervendo, em exibição no Teatro Rival, "todas as noites às 20 e 22h. Vesperais às 5as. e domingos, às $16 \mathrm{~h}$."

81 http://www.bolsademulher.com/estilo/rogeria-o-melhor-de-dois-sexos-3, sem data da publicação. Acesso: 16/05/2016.

82 ARAÚJO, Paulo César. Eu não sou cachorro, não. São Paulo: Record, 2002, in: A trilogia homossexual de Agnaldo Timóteo. Disponível em: http://www.memóriamhb.blogspot. com/2012/06/ trilogia-homossexual-de-agnaldo-timoteo.html, acesso: 17/05/2016.

83 Programa televisivo de entrevistas Perfil \& Opinião (não informados a emissora, tampouco o ano). Disponível em https://www.youtube.com/watch?v=QKDxeJyUTmA. Acesso: 17/05/2016.

84 GREEN, op. cit., p. 365, 373; CELESTE, entrevistas pessoais concedidas em, [2013] 2014.

85 Jornal do Brasil, domingo, 29/11/1964, $1^{\circ}$ Caderno, p. 35; Jornal do Brasil, Caderno B, p. 2, terça-feira, 01/12/1964.

86 Jornal do Brasil, edições diárias, de 1960 a 1969.

87 Entrevistas concedidas em 18/10 e 07/12/2014.

88 ELIAS, Jorge. O Cavaleiro da Concórdia. O homem do outro mundo. Nova Iguaçu: Racional, p. 29. Disponível em: http://pt.scribd.com/doc/27643005/Cavaleiro-da-ConcordiaO-homem-de-outro-mundo. Acesso: 11/11/2014.

89 ANTÔNIO, op. cit., p. 226.

90 OLIVEIRA, Neuza Maria de. Damas de Paus: O jogo aberto dos travestis no espelho da mulher. Salvador: Centro Editorial e Didático da UFBA, 1994.

91 CELESTE, entrevistas pessoais concedidas de 19 a 22 de junho de 2014.

92 Entrevista pessoal de Suzy Parker e Yeda Brown em 07/12/2014. Diário de Minas, 13/11/1970 e Jornal da Cidade, BH, 18/08/1970. Agradeço ao pesquisador Luiz Morando pela generosidade em ceder suas fontes de periódicos mineiros.

93 Somente cerca de um ano depois, quando o Quarteto em Cy quis gravar a música tema da peça, é que foi conseguida a sua liberação (da música apenas), mas sob a condição de que o seu nome fosse trocado. Sugestão acatada, a marcha-rancho, que se chamava $A$ Marcha da bicha louca, passou a se chamar Nabucodonosor, que seria o personagem a ser representado por Rogéria. Vale conferir a letra, pela sua criatividade, ao fazer troça com uma imaginada situação constrangedora vivida por uma bicha durante um baile de fantasias do carnaval: "Nunca mais quero sair fantasiado / Nunca mais quero brincar no carnaval / Nunca mais, ai, nunca mais serei vaiado / Naqueles bailes do Municipal / Foi no ano passado, eu me fantasiei, imaginem vocês / Fui pra lá carregado, todo enfeitado, com mil paetês / Com miçangas e vidrilhos, apliques, lantejoulas / Bordados eu tinha até mesmo nas minhas ceroulas / Quantas noites tive que ficar acordado / Quantas noites eu cheguei mesmo a passar mal / Quantas noites eu caprichei nos meus babados / Pra quase ir em cana no final / Começou o desfile, a fofoca comia em pleno salão/ Sonho de Messalina, não sabe de quem, levou um bofetão / Esplendor Renascentista foi desclassificado / Aí deu um pulo pra cima e caiu desmaiado / Foi então que desisti de desfilar / Foi então que abandonei a passarela / Foi então que começaram a me estranhar / E o povo já gritava prende ela / E o povo já gritava prende ela / Terminou o desfile eu só não chorei porque não sou mulher / E mesmo que fosse, eu nunca seria como uma qualquer / Fui 
pra minha casa curtindo a minha dor / Rasgado e amassado de Nabucodonosor". Jornal do Brasil, 22/02/1973, $1^{\circ}$ Caderno, p. 5; HORTÊNCIO, Luciano. Nabucodonosor, a marcha-rancho de Stanislaw Ponte Preta. In: Jornal GGN, Luís Nassif on line, 04/08/2015. Disponível em: http://jornalggn.com.br/blog/lucianohortencio/nabucodonosor-a-marcha-rancho-de-stanislawponte-preta. Acesso: 16/05/2016.

94 Jornal do Brasil edições do ano de 1973. Disponível na: Hemeroteca digital da Biblioteca Nacional.

95 CELESTE, entrevistas pessoais concedidas de 19 a 22 de junho de 2014.

96 PARKER, Suzy. Entrevista pessoal à autora em 18/10/2014.

97 RODRIGUES, Rita de C. C. Poder, gênero, resistência, proteção social e memória: aspectos da socialização de "gays" e "lésbicas" em torno de um reservado no São João de Meriti, no início da década de 1980. Dissertação (Mestrado em Política Social), Universidade Federal Fluminense, Niterói, 2006. Disponível em: <http://lakh.unm.edu/ handle/10229/20691?show=full $>$. Acesso em: 02 mar. 2014.

Artigo recebido em abril de 2016. Aceito em julho de 2016. 